\title{
Coal-bearing capacity of the Petřkovice Member (Ostrava Formation, Serpukhovian, Mississippian) of the Upper Silesian Basin (Czech Republic and Poland)
}

\author{
Lada HÝLOVÁ ${ }^{1}$, Jakub JIRÁSEK ${ }^{2, *}$, Martin SIVEK² and Janusz JURECZKA ${ }^{3}$ \\ 1 Palacký University, Faculty of Science, 17 listopadu 12, 77146 Olomouc, Czech Republic \\ 2 VŠB-Technical University of Ostrava, Faculty of Mining and Geology, 17 listopadu 15/2172, 70833 Ostrava-Poruba, \\ Czech Republic \\ 3 Polish Geological Institute - National Research Institute, Upper Silesian Branch, Królowej Jadwigi 1, 41-200 Sosnowiec, \\ Poland
}

\begin{abstract}
Hýlová, L., Jirásek, J., Sivek, M., Jureczka, J., 2016. Coal-bearing capacity of the Petřkovice Member (Ostrava Formation, Serpukhovian, Mississippian) of the Upper Silesian Basin (Czech Republic and Poland). Geological Quarterly, 60 (3): 637-649, doi: 10.7306/gq.1283

The Petřkovice Member is the basal unit of the paralic succession of the Ostrava Formation of the Upper Silesian Basin. This member is a valuable source of information about the transition from a marine basin filled with siliciclastic sediments into a paralic basin with the beginning of coal-bearing sedimentation. Models of: (1) the number of coal seams, (2) their total thickness, and (3) the coal content with respect to the total thickness of the succession were created to describe and assess the coal-bearing capacity of the Petřkovice Member. The authors present models for coal seam thicknesses exceeding either 10 or $40 \mathrm{~cm}$. The coal-bearing capacity of the Petřkovice Member is very low. The average share of coal seams thicker than $0.1 \mathrm{~m}$ is $3 \%$. The share of coal seams with a thickness that exceeds $0.4 \mathrm{~m}$ is only $1.66 \%$. Moreover, in large areas of the basin, in the N and NE parts, the coal-bearing capacity is close to zero, because coal seams of greater thickness were detected only locally there. Based on these models and on other geological data, it is obvious that the onset of coal sedimentation was gradual and limited to particular sites showing the greatest subsidence of the basin floor. In places where minor subsidence took place, there were likely unfavorable conditions for accumulation of organic matter.
\end{abstract}

Key words: Upper Silesian Basin, Serpukhovian, Mississippian, Carboniferous, coal-bearing capacity.

\section{INTRODUCTION}

The Upper Silesian Basin (hereinafter referred to as the USB) is currently economically the most important European bituminous coal basin. The annual output of the USB amounts to about 70.2 million tons of bituminous coking and thermal coal. The majority of the production comes from Poland (61.6 mil tons in 2013; Malon and Tymiński, 2014), where approximately four-fifths of the area of the basin is situated. A total of 8.6 mil. tons (Starý et al., 2014) were extracted in 2013 in the Czech Republic, where the remaining part of the basin is located.

The Petřkovice Member is the oldest lithostratigraphical unit of the Ostrava Formation, which represents the paralic stage of the development of the USB. The results of the investigation contribute to knowledge of the nature of the transition from relatively deep sea flysch sedimentation of the Moravian-Silesian Basin into the coal-bearing sedimentation of the paralic development of the USB. Simultaneously, this study contributes to

\footnotetext{
* Corresponding author, e-mail: jakub.jirasek@vsb.cz

Received: September 1, 2015; accepted: December 17, 2015; first published online: March 1, 2016
}

the knowledge of general factors controlling the development of coal-bearing basins in the foreland position of the Variscan orogeny. Hýlová et al. (2013) recognized the geological significance of analysis of the overall thickness and the content of sand in the Petřkovice Member.

This study of coal-bearing capacity illustrates the variable conditions that prevailed after the transition from marine to paralic sedimentation. As examples, authors provide maps of the total coal-bearing capacity (sum of all coal seams thicker than $0.1 \mathrm{~m}$ ) and maps of economic coal-bearing capacity (sum of coal seams $>0.4 \mathrm{~m}$ ). The coal-bearing capacity of the Ostrava Formation has been the subject of many studies, papers and unpublished reports (e.g., Folprecht, 1928; Havlena, 1964; Kotas and Malczyk, 1972; Adamusová et al., 1992; Gabzdyl, 1994; Konstantynowicz, 1994; Jureczka and Kotas, 1995; Kaštovský and Dopita, 1997; Pešek et al., 1998), but they have never focused on a single lithostratigraphical unit over its whole extent.

\section{GEOLOGICAL SETTING}

The USB was formed during the final stages of the evolution of the Moravo-Silesian Paleozoic Basin (Unrug, 1966), situated in the eastern domain of the Central European Variscides (Kro- 
ner et al., 2008). The USB is a typical example of the foreland basin of the Variscan Orogen, later enclosed in the outer zones of the orogenic belt, termed Rhenohercynicum and Subvariscicum (Kumpera and Martinec, 1995; Narkiewicz, 2007).

The post-erosional boundaries of the USB have an approximately triangular shape, shared between Poland and the Czech Republic. The area of coal basin exceeds $7,000 \mathrm{~km}^{2}$. The major part $(\sim 78 \%)$ lies in Poland (Dembowski, 1972; Dopita et al., 1997).

The basement of the basin is formed by the sedimentary cover of the Brunovistulicum Terrane, representing a microcontinent situated at the southern margin of Baltica in the Early Paleozoic. Cambrian, Ordovician, Devonian and Mississippian strata have been identified in the sedimentary envelope of the Brunovistulicum (Kalvoda et al., 2008; Buła et al., 2015). Carboniferous sedimentation began with pre-orogenic carbonates. The effect of the Variscan orogeny is recognizable in a sequence of marine siliciclastic flysch deposits (Culm facies) with pre-erosional thicknesses of up to $11 \mathrm{~km}$ (Francu et al., 2002). Sedimentation continued through the coal-bearing paralic and later terrigenous molasse before and also after the final collapse of the orogen and termination of the associated tectonic events (Dopita et al., 1997).

The coal seams in the USB, containing mostly bituminous coal, were formed during the Late Carboniferous (Namurian to Westphalian in the western European subdivision). Two major sedimentary units have been distinguished in the Carboniferous coal-bearing succession: paralic and terrigenous sequences (Figs. 1 and 2). An older, paralic type of sedimentation, with a wide spectrum of sedimentary environments, has been documented (e.g., Kędzior et al., 2007). Sequences consist of terrestrial clastic deposits with intercalations of ca. 200 faunal horizons, of which about 80 contain a sporadic marine fauna. The deposits are arranged into cyclic patterns, studied by several authors, who identified three orders of cyclic arrangement; megacycles, mesocycles and basic cycles. This subdivision depends mainly on the intensity of marine incursions (Jansa and Tomšík, 1960; Zeman, 1960; Gastaldo et al., 2009).

This type of sedimentation is characterized by the cyclic alternation of clastic sediments with coal seams. Frequent intercalations of volcanoclastic materials (coal tonsteins [e.g., tuffs] and whetstones [e.g., tuffites]) have been documented. The entire paralic succession is known as the Ostrava Formation in the Czech Republic or the Paralic Series in Poland. These units consist of the Petřkovice, Hrušov, Jaklovec and Poruba members (in Poland, informal lithostratigraphic units) and were deposited in the period from $\sim 330$ to $\sim 324 \mathrm{Ma}$, covering almost the whole Serpukhovian Stage (Jirásek et al., 2013b and unpublished data of authors). The younger, continental deposits, characterized by lack of marine or brackish horizons, deposited after a significant stratigraphic gap occur across the whole ba$\sin$. The coal seams here are usually thicker than in the older part, occasionally up to $24 \mathrm{~m}$. Volcanoclastic material is also present here but is less frequent. Cyclic patterns of sedimentation are recognisable, but differ from those of the paralic part in the average thickness of basic cycles and in other parameters (e.g., Havlena, 1982). In the Czech part of the basin this succession, called the Karviná Formation, belongs to the Bashkirian and consists of the Saddle, Suchá and Doubrava members (Dopita et al., 1997). In the Polish part of the basin, sedimentation continued up to the Gzhelian and consists of the Upper Silesia Sandstone, Siltstone and Kraków Sandstone units, composed of 7 subunits (Fig. 1; Dembowski, 1972; Kotas et al., 1988). The exact stratigraphic position of the Jejkowice Member, known only locally as an interbed between the
Ostrava and the Karviná formations (resp. Paralic and Upper Silesia Sandstone units), is unknown (Jureczka, 1988).

\section{MATERIALS AND METHODS}

Logs of exploration boreholes were the principal data source for creating the data files used for modelling the development of the Petřkovice Member. On the Czech side, the database of exploration boreholes from the Department of Mineral Resources and Modelling at the Faculty of Mining and Geology, VŠB-Technical University of Ostrava, were used, supplemented with information from the Czech Geological Survey. On the Polish side, the database of exploration boreholes from the Upper Silesian Branch in Sosnowiec of the Polish Geological Institute, National Research Institute, were used.

Exploration boreholes were drilled from the beginning of the 20th century, although most were drilled in the second half of the last century. Thus, because of developments in drilling technology and data interpretation, the data file is diverse and it was necessary to individually consider the inclusion of boreholes into this file.

A total of 404 drilling logs of exploration boreholes which penetrated the Petřkovice Member were available from the whole of the basin. However the majority did not have a complete drilling log and, therefore, could not be used for modelling of the coal-bearing capacity of the Petřkovice Member. 206 boreholes did not reach the bottom of this unit, while for 75 boreholes the roof of the unit was missing due to erosion. A total of 65 verified complete logs and two incomplete drilling logs were used for modelling. For the two incomplete logs, the missing parameters were calculated using correlation with the closest datapoints. The apparent thicknesses of coal seams were converted into the true thicknesses using inclination values specified in the logs. The final values included all types of coal with various ash contents. Only carbonaceous shales and shaly coals were excluded from the calculations.

The method of bisecting the distances between the positive and the negative boreholes was used to construct the models of coal-bearing capacity of the Petřkovice Member in the basin. This means that for the modeled parameter the zero isoline is given in the half distance between the last point with known value and the first (closest) point with zero value. Output maps were created using the InRoads and MicroStation 8.5 programs (Bentley Systems, Inc.). A method of interpolation between triangles formed by the known documentation points was used in the inner part of the model, while an extrapolation method was used between the end points and the boundary. Models in areas without known values adjacent to the extrapolated values were based on expert estimation.

Regional chronostratigraphic units were used in the text, in addition to international nomenclature of the Late Carboniferous subdivision in Western and Central Europe (cf. Menning et al., 2006; Davydov et al., 2012).

\section{THE PETŘKOVICE MEMBER IN THE USB}

The Petřkovice Member is the oldest lithostratigraphic unit of the USB. Sedimentation started at the end of the purely marine siliciclastic flysch sedimention of the Hradec-Kyjovice Formation in the Czech Republic or the Malinowice Member in Poland. Zircon age dating of the top of the Petřkovice Member gives 327.25 $\pm 0.15 \mathrm{Ma}$ (Jirásek et al., 2013a), while the base of the unit is approximately $329.7 \mathrm{Ma}$ (Jirásek et al., 2013b). The 


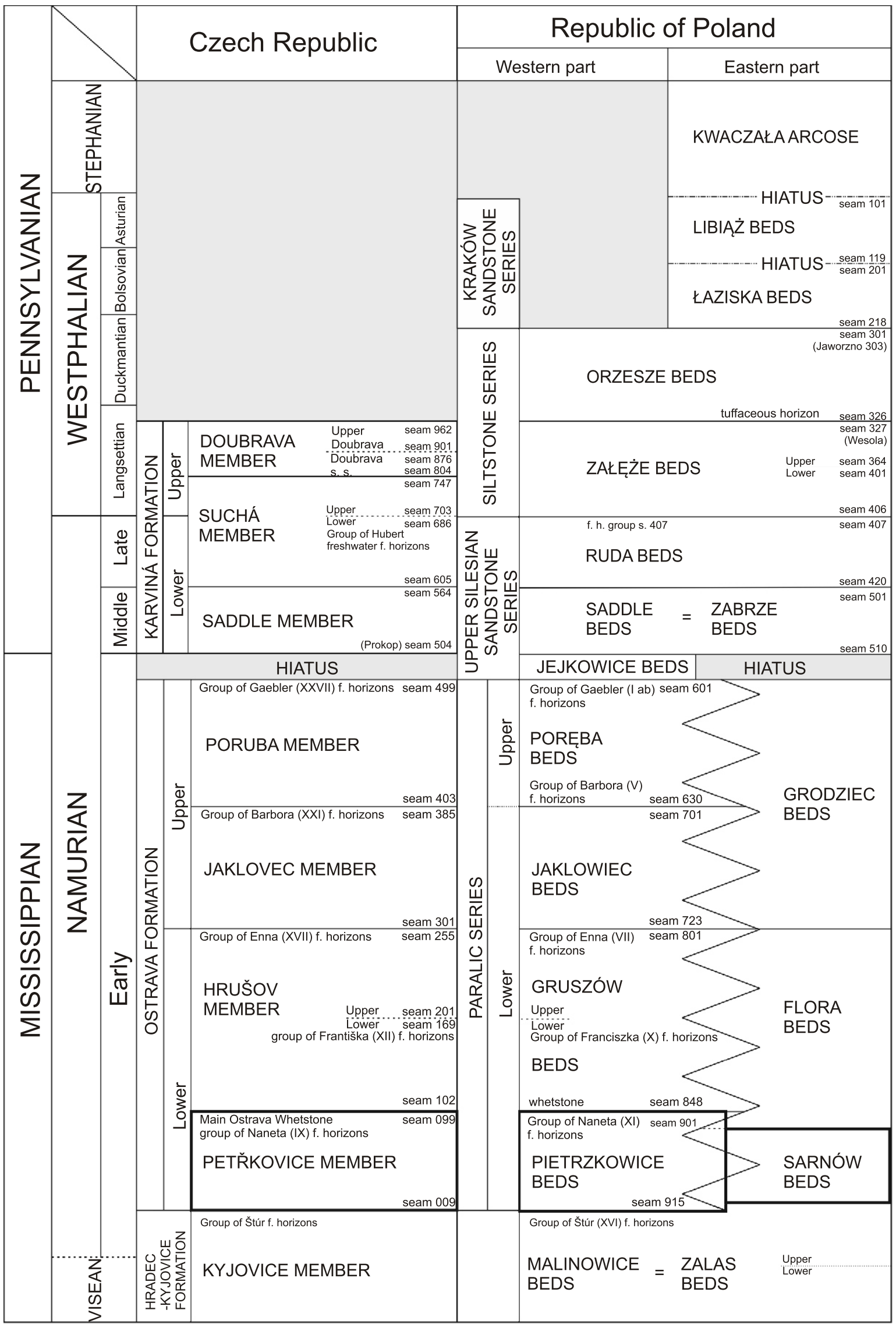

Fig. 1. Lithostratigraphic division of the Czech and Polish parts of the Upper Silesian Basin 


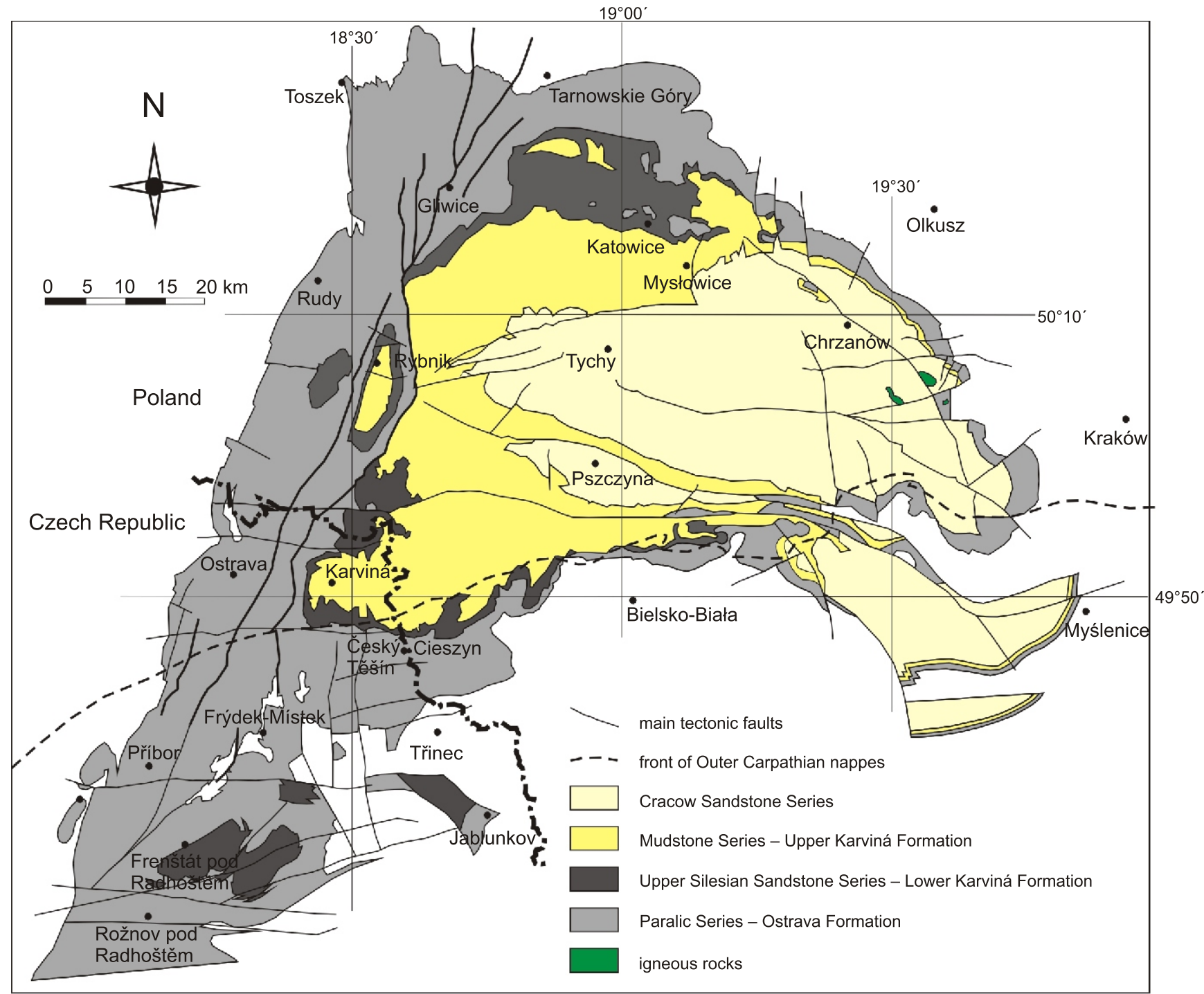

Fig. 2. Geological map of the sedimentary infill of the Upper Silesian Basin indicating the main lithostratigraphic units

According to Aust et al. (1997) and Jureczka et al. (2005), modified

change in sedimentation from marine to paralic conditions seems likely to be linked with global glacioeustatic events, so that the base of the Petřkovice Member can be roughly correlated with the Visean/Serpukhovian boundary. The Visean/Serpukhovian boundary itself lies in the upper part of the Hradec/Malinowice Member, according to the goniatite fauna. However, the use of biostratigraphic methods is limited due to the lack of index fossils in all formations. For this study, we used the definition of the Petřkovice Member boundary specified by Hýlová et al. (2013). That is to say, the Petřkovice Member is separated from the older Kyjovice Member (or equivalent Malinowice or Zalas Beds) by the roof of the Štúr Faunal Horizons Group and its upper boundary is determined by the roof of the Main Ostrava Whetstone horizon. In places where the Whetstone horizon is not developed, the upper boundary of the Petrrkovice Member is placed at the top of the marine (locally even freshwater and Lingula-bearing, i.e. brackish) horizons of the Naneta Group.

The post-erosional area of the occurence of the Petřkovice Member is almost identical to the present-day extent of the USB. Erosion of the Carboniferous massif and the later nearby development of the Carpathian orogenic belt had a decisive in- fluence on the current areal extent of the Petřkovice Member and the depth of its burial below the present-time surface. This is reflected in the irregular degree of exploration of the unit expressed by borehole distribution over the USB area (Fig. 3). The unit is best recognized along the western and northeastern boundary of the USB, where the strata are exposed on the post-erosional surface of the Carboniferous or very close to it. In these parts of the basin, some coal seams have been exploited (the Heřmanice, Mariánské Hory, Paskov, Petřkovice, Prrívoz, Stařič, and Svinov mining fields in the Czech Republic; the Gliwice mining field in Poland). In the remaining areas of the ba$\sin$, there has been less geological exploration of the Petřkovice Member, thus its recognition and analysis is less reliable. Towards the east, an increasing number of younger stratal units is preserved in the roof of the Petřkovice Member. In some areas, particularly in the Polish part of the basin, deposits of the Petřkovice Member and its counterpart Sarnów Beds occur at depths beyond the technical and economic possibilities of exploitation. The coal-bearing capacity of the Petřkovice Member decreases approximately in an eastern direction. The poor level of exploration in the eastern part of the basin in Poland is mainly a result of different facies development (see Fig. 1). By contrast 


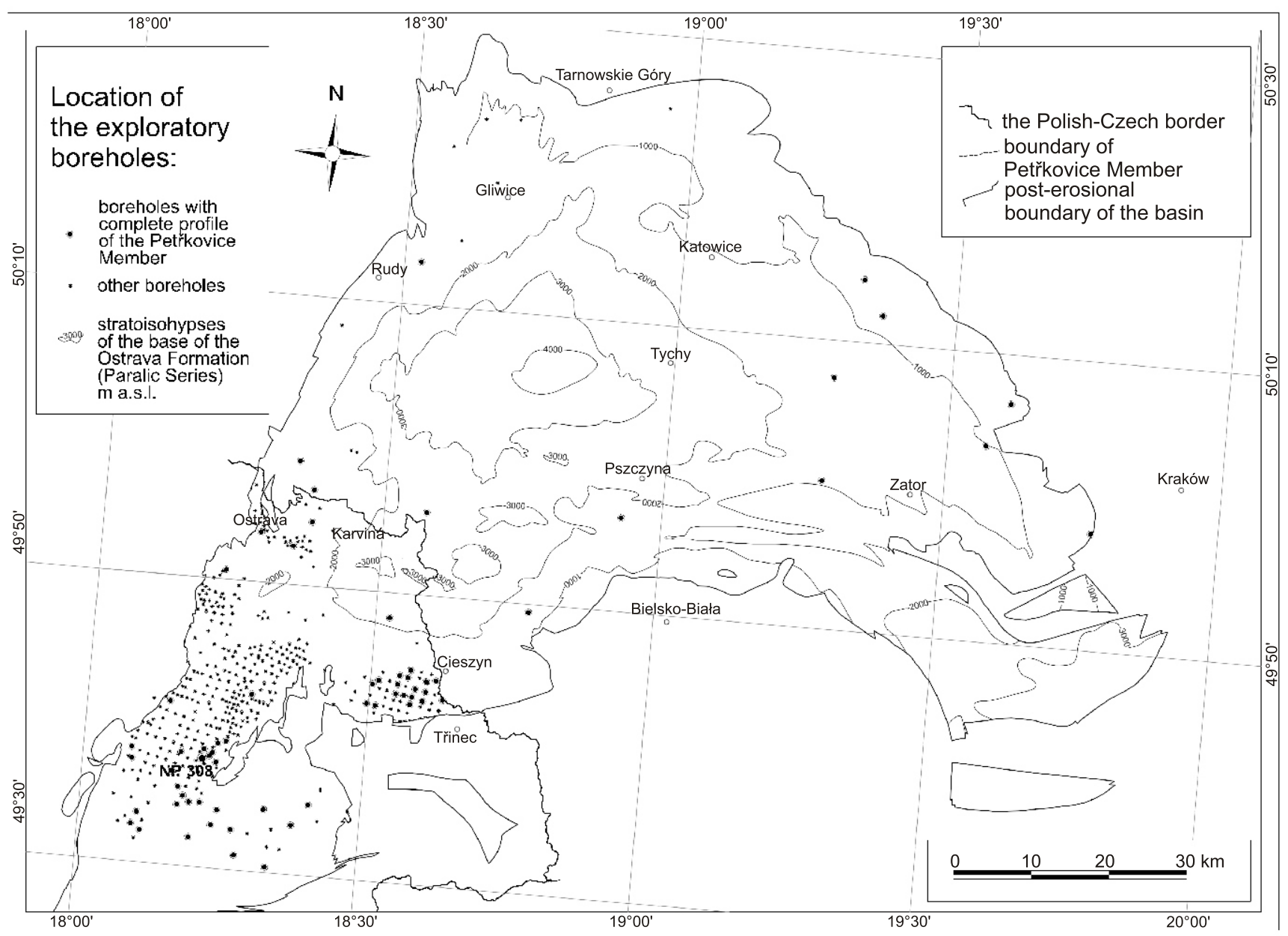

Fig. 3. Distribution of exploration boreholes in the Upper Silesian Basin that penetrate strata of the Petřkovice Member

An approximate scheme of the base of this stratal unit in areas with low density of boreholes is according to Jureczka et al. (2005)

with the Petřovice Member, the Sarnów Beds consist of a thin lithosome of coarser-grained deposits. These are coal-barren terrestrial deposits in the roof of an almost purely marine succession that is poorly explored, where only a few thin coal seams are locally known. Their primary description given by Doktorowicz-Hrebnicki (1935) is rather vague, and detailed information on the transition of the Petrrkovice Member to the the Sarnów Beds is not available. For the study purpose, the border between those two units was established in places where the unit's sand content exceeds $75 \%$ and at the same time its thickness is $<300 \mathrm{~m}$. Such a division essentially corresponds to the first description of the Sarnów Beds (Doktorowicz-Hrebnicki, 1935). Towards the SSE, the thickness of the overburden grows as coal-bearing deposits of the USB become covered by the Outer Western Carpathians nappes.

The coal seams of the Petrrkovice Member according Martinec et al. (2005) show a generally simple development of coal, which mostly consists of coal macrotypes typical of a higher degree of coalification, (i.e., banded bright coal and banded coal). The prevailing microlithotype of coal is vitrinite. Macerals of the liptinite group are preserved only in parts with a lesser degree of coalification (Jurczak-Drabek, 1996; Sivek et al., 2003). The degree of coalification calculated from the $\mathrm{V}^{\text {daf }}$ (Sivek et al., 2008) ranges between a mean vitrinite reflectance $R_{o} 0.5$ to $2.6 \%$ (Kandarachevová et al., 2009) in the western part of the basin, while in the northeastern and eastern parts the $R_{o}$ value is $<0.8 \%$ (Jurczak-Drabek, 1996). Such variability in the degree of coalification probably reflects largely secondary reasons. The most prominent one is the difference in the thickness of overlying strata in the past.

\section{COAL-BEARING CAPACITY}

The coal-bearing capacity is a commonly used parameter for the analysis of coal basins, which can be defined in several ways: (1) the total thickness of coal seams in the observed succession; (2) the number of coal seams within the observed section of the stratal sequence; and (3) the net content (\%) of coals within the succession. The term "coal-bearing capacity" is usually used for the determination of coal content in strata but is also used to estimate the amount of coal reserves in areas of low level of recognition. The first two methods for the determination of coal content are mainly used in sedimentological studies. The absolute coal-bearing capacity is a parameter used for all coal seams, regardless of their thickness. Other coal-bearing capacities are referred to as relative. However, the absolute coal-bearing capacity takes into account the minimum thickness of the coal seams that are included in the calculation of the coal-bearing capacity (usually $0.1 \mathrm{~m}$ ). Without thickness limits, information on coal-bearing 
capacity is not informative and is, therefore, not useful for further interpretations or other applications.

For this analysis of the sedimentary environment of the Petřkovice Member deposits and the accompanying palaeogeographic reconstruction, the authors used all of the above-mentioned methods to create their models. Because of the generally smal thicknesses of coal seams of the Petřkovice Member, we have compiled models of coal-bearing capacity for limiting thicknesses of 0.1 and $0.4 \mathrm{~m}$, respectively. The coal-bearing capacity, usually expressed by the total thickness of coal seams (Fig. 4), is the basis for assessment of the spatial distribution of peat sedimentation in the coal basins, while models of coal-bearing capacity, which are usually based on the content of the coal seams (Fig. 5) or expressed by the number of coal seams (Fig. 6), are usually considered complementary.

\section{TOTAL THICKNESS OF COAL SEAMS}

The coal-bearing capacity expressed by the total thickness of the coal seams is a parameter traditionally used to study the history of the development of coal basins. The authors calculated the coal-bearing capacity under two alternative scenarios; for limiting thicknesses of either 0.1 or $0.4 \mathrm{~m}$ (Fig. 4). Both models were created using contours with an interval of $5 \mathrm{~m}$.

For the coal-bearing capacity of the Petřkovice Member (Fig. 5), the $\mathrm{N}-\mathrm{S}$ polarity prevails over the $\mathrm{E}-\mathrm{W}$ polarity. Based on the authors' models of coal-bearing capacity, this pattern is quite evident, so that the higher coal-bearing capacity was recorded only in the Czech part of the basin (Figs. 4 and 5). In this part, the coal-bearing capacity is actually characterized by great variability and a random spatial distribution. In the Polish part of the basin, the coal-bearing capacity is not zero, but varies over very low values.

The coal-bearing sedimentation of the Petřkovice Member does not replicate the characteristic NNE-SSW direction, which is mostly involved in the development of the paralic molasse of the USB and which was primarily connected with the differences in thickness of the deposits and (partly) their sand content. As is evident from this study, the importance ot this direction is not restricted to the development of the Petřkovice Member thickness and sand content, but is also reflected in their coal-bearing capacities.

The model of coal-bearing sedimentation at the limiting thickness of $0.4 \mathrm{~m}$ supports the existence of areas with greater total thicknesses of coal seams, as was observed in the model with the limiting thickness of $0.1 \mathrm{~m}$. There are three such areas, all of which are located in the Czech (SW) part of the USB. The two larger ones occur in the western part of the posterosional occurrence of the Petřkovice Member, whereas the third, the smallest, lies in the Karviná part, south-west of the town of Těšín (Fig. 4).

THE PROPORTION OF TOTAL THICKNESS OF COAL SEAMS AND NUMBER OF COAL SEAMS IN THE OBSERVED SECTION OF THE STRATAL SEQUENCE

Coal-bearing capacities expressed as net content of the coal and the number of coal seams in the succession are, in sedimentological analyses of the evolution of coal basins, considered as complementary to coal-bearing capacity expressed as the total thickness of the coal seams. Both types of coal-bearing capacity presented in this study were prepared under two alternative scenarios (i.e., for limiting thicknesses of 0.1 and $0.4 \mathrm{~m}$ ). Models of coal-bearing capacity were developed in the form of contour lines with an interval of $2 \%$ (Fig. 5). Models presented as the number coal seams in the observed section of the stratal sequence are shown in Figure 6. These models have been developed in the form of contour lines, with an interval of 20 for the type expressing the number of coal seams with a thickness of $>10 \mathrm{~cm}$, and an interval of 10 for the distribution of coal seams with a thickness of $>40 \mathrm{~cm}$.

All models confirm the north-south trending polarity (NNE-SSW direction) of the coal-bearing capacity of the Petřkovice Member prevailing over the $\mathrm{E}-\mathrm{W}$ trending polarity. The models created for the limiting thickness of $40 \mathrm{~cm}$ document an absence of coal seams of greater thickness in the whole of the northern and eastern parts of the USB, where coal seams $>40 \mathrm{~cm}$ are only locally identified. It should be noted that all of those parts are poorly recognized by both boreholes and mine workings. The models of spatial development based on net coal content and number of the coal seams maintain (except for small differences) the major features of the development observed in models of the total thickness of coal seams in the Petřkovice Member.

\section{DISCUSSION}

As noted above, the coal-bearing capacity of the Petřkovice Member is very low. The average value of the coal seams content $>0.1 \mathrm{~m}$ has been established at $3 \%$, however, the value of the coal seam contents $>0.4 \mathrm{~m}$ is only $1.66 \%$. Moreover, this coal-bearing capacity in the $\mathrm{N}$ and NE parts is in the range of 0 to $2 \%$, with coal seams of greater thickness being mostly absent.

All models confirm the prevailing $\mathrm{N}-\mathrm{S}$ trending polarity (or elongation of the main zones of coal-bearing capacity along approximately a NW-SE direction). This direction is strikingly reminiscent of the direction of major tectonic zones in the broader area (Kraków-Lubliniec Fault Zone - e.g., Buła, 2000; Haná Fault Zone - Dudek, 1980), defining the northern and southern boundaries of the Upper Silesia Block of Brunovistulicum in the basement of the USB (cf. Buła and Żaba, 2005). These trends are likely to have played an important role in the development of the underlying sedimentary accumulation of the USB and of sediments of the Petřkovice Member, especially in its lower part (Hýlová et al., 2013), where they represent a manifestation of subsidence-related transition of the Visean sedimentary basin into the paralic molasse of the USB.

For the new emerging stage of development of the depositional area of the Moravo-Silesian Basin, corresponding to the USB (or to its paralic molasse), it is clear that transition to the coal-bearing sedimentation was not synchronous across the whole basin, but undoubtedly started on its southern edge and proceeded to the north. Therefore, the southern part of today's post-erosional extent of the basin was affected first by transition to the terrestrial sedimentary environment, whereas the northern part of the basin was affected later and with less intensity. This fact is reflected in the increased coal-bearing capacity in the Czech part of the basin, particularly in its southern part. Coal-bearing capacities close to zero were often found in the northern and southeastern parts of the Polish part of the basin, where regions without coal-bearing sedimentation are also found.

A complicated development of depositional conditions in the south of the Czech part of the USB has previously been described by one of the authors of this study (Hýlová, 2011). This evolution was also previously the subject of investigation of the coal-bearing capacity and development of the thickness and sand content of the Petřkovice Member of the USB (Hýlová et al., 2013). A development of foreland basin type can be applied to the stage of paralic sedimentation of the Petřkovice Member, 


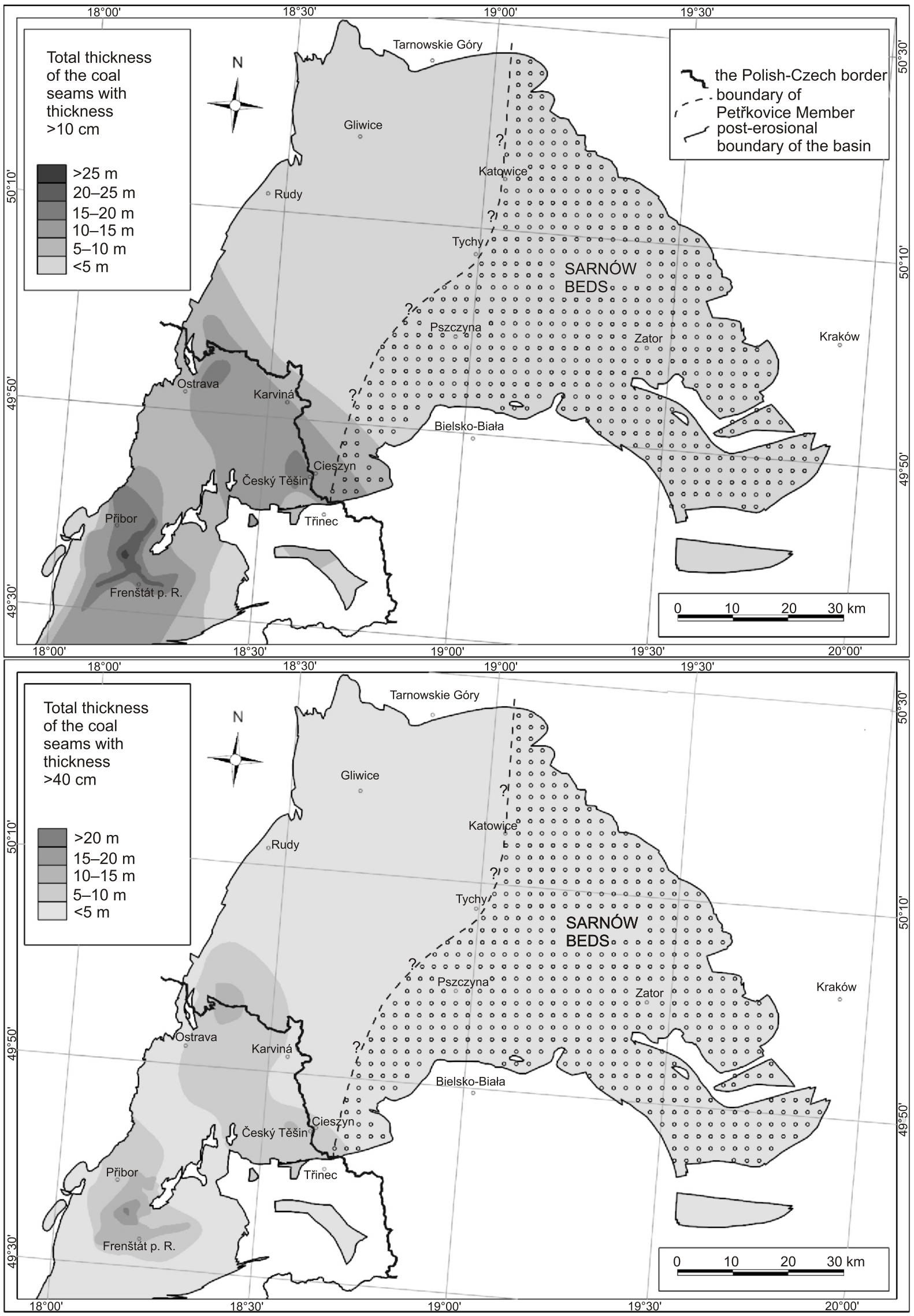

Fig. 4 Models of total thickness of coal seams $>10$ and $>40 \mathrm{~cm}$ 


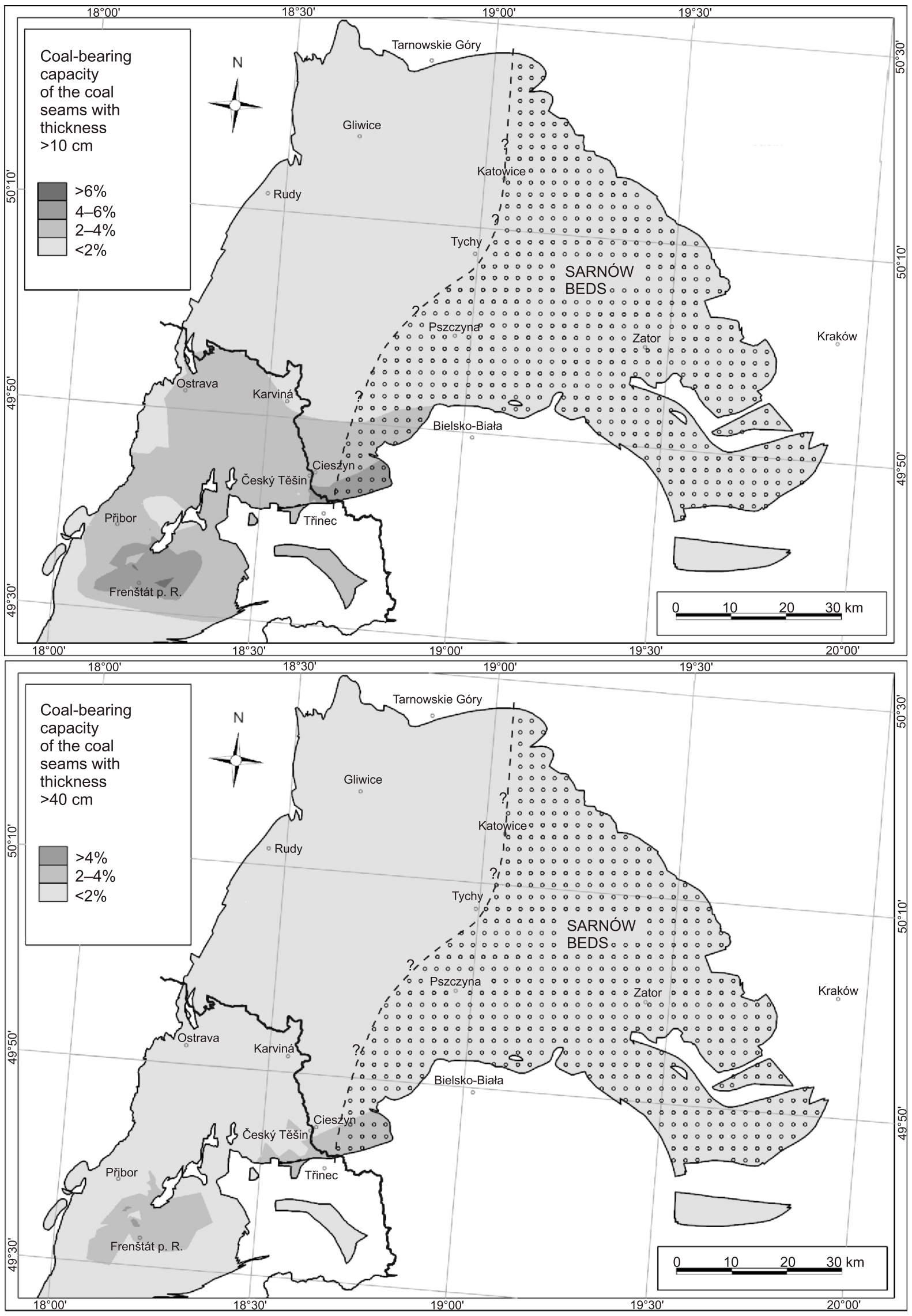

Fig. 5. Models of coal-bearing capacity $(>10$ and $>40 \mathrm{~cm})$ expressed as the proportion (\%) of coal in strata of the Petřkovice Member 


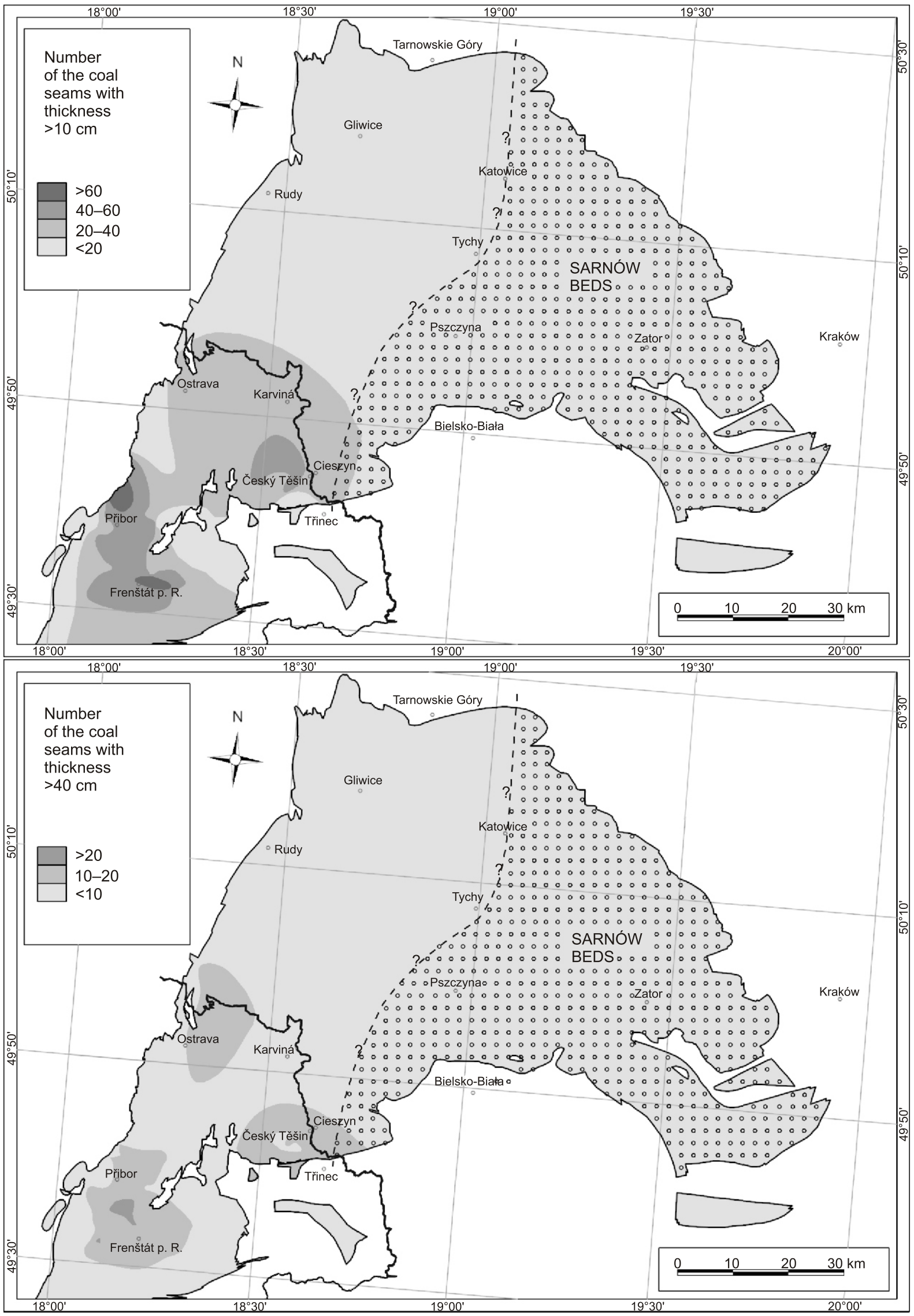

Fig. 6. Models of the number of coal seams $(>10$ and $>40 \mathrm{~cm})$ of the Petřkovice Member 


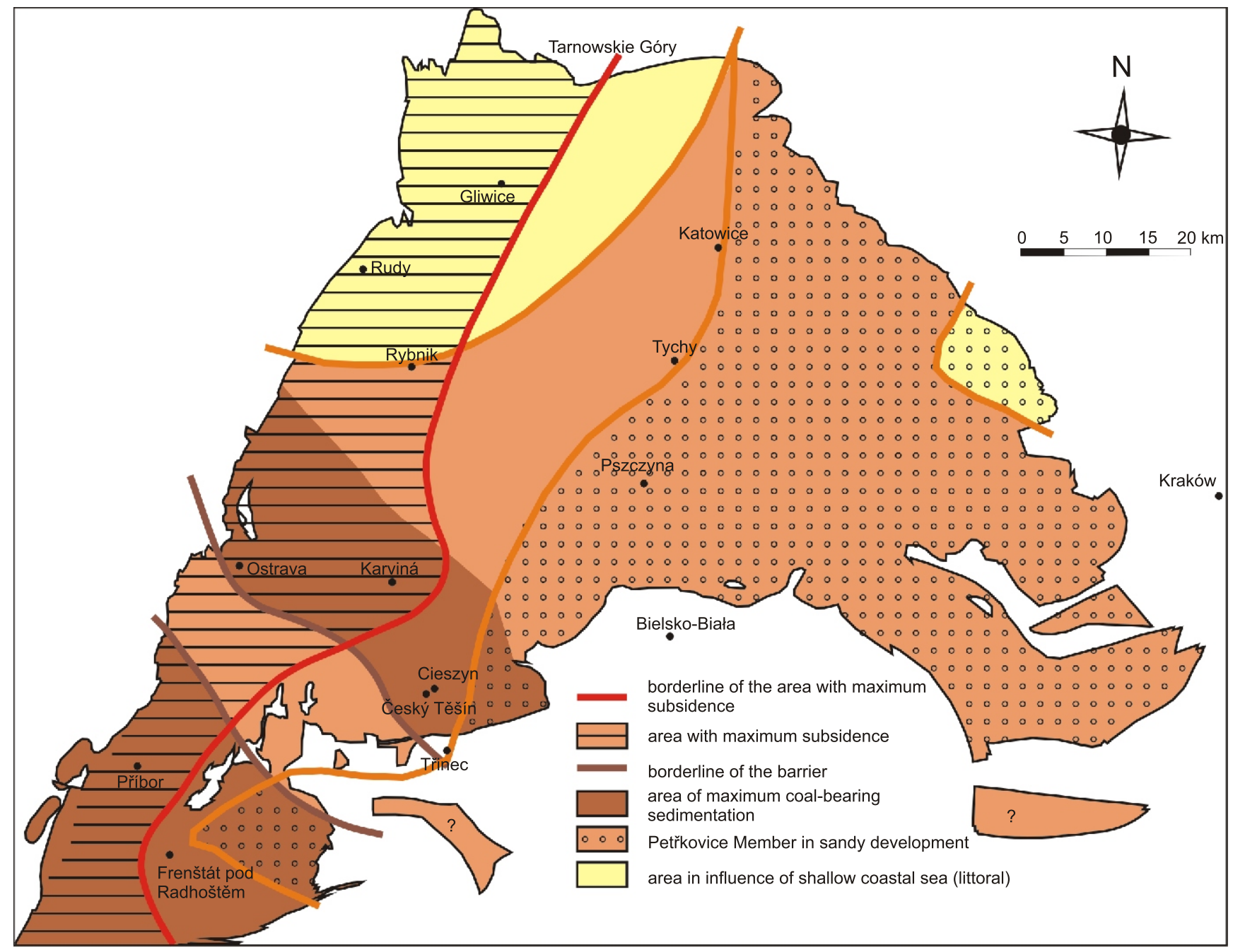

Fig. 7. Inferred zones of different geological development of the Petřkovice Member in the Upper Silesian Basin

which is best seen along an $\mathrm{E}-\mathrm{W}$ direction. This trend is evident to the north of the Czech part of the basin and throughout its Polish part, both in the development of the thickness of coal seams and in its sand content. In the centre and south of the Czech part of the basin, this situation is complicated and obscured by a local NW-SE trending belt with anomalously low thicknesses and increased sand content (Hýlová et al., 2013), and also low total thickness (Fig. 4) and number of coal seams (Fig. 6). We interpret this structure as a zone of littoral drift barriers (Fig. 7). These are likely to have prevented frequent marine incursions into the southern parts of the basin and also induced changes in the development of faunal horizons, which is also manifested by their gradual transition from marine to brackish, and later to freshwater horizons, in the same direction.

Despite the anomalous development in the south of the Czech part of the basin, it is obvious that, in the USB as a whole, segments characteristic of foreland type basins (such as foredeep, forebulge and backbulge) can be seen. The best example is the northern part of the basin, where such development prevails. Also dominant in this part of the basin is the separation of the depositional area into three characteristic zones of foreland types of basin. These include the foredeep with maximum subsidence, which is located in the western part of the post-erosional area of the Petřkovice Member, the zone of transient subsidence and the zone of minimum subsidence in the east of the basin. The two areas of maximum coal-bearing sedimentation during the deposition of the Petřkovice Member are both located in the foredeep segment, where the depocentre is located (Fig. 7). The third, the smallest of the three, lies in a transitional zone, where the coal-bearing capacity is at its minimum in the area of negligible subsidence. In the north of the basin, where the paralic sedimentation took place only slowly and diachronously, the coal-bearing capacity is also close to zero.

The relative proximity of a sea and numerous marine incursions into the basin are considered to have played an important role in the distribution of the coal-bearing capacity of the Petřkovice Member. The spatial variability of regions with higher coal-bearing capacities may be partly attributed to the synsedimentary erosion of coal seams by river channels (Filák, 2006). The analyses of younger sedimentary units are not yet complete, but the preliminary results show that the pattern of the coal-bearing capacity of the Petřkovice Member likely differs considerably from that of the younger members of the Ostrava Formation. Although a diminishing effect of the change in conditions at the marine/paralic sedimentary boundary can be recognized during the formation of the Petřkovice Member, newly incoming trends can also be seen. Based on models of the coal-bearing capacity of the unit as well as on previously published models of thickness development and sand content of the unit (Hýlová et al., 2013), the following conclusions can be derived: (1) the coal-bearing sedimentation of the Petřkovice 
Member is closely related to the overall thickness of the unit and to basin basement areas of greatest subsidence; (2) an increase in the sand content led to the suppression of the cyclic structure in the Petřkovice Member and, consequently, to a reduction in their coal-bearing capacities. A larger supply of coarse-grained fluvial sediments was not favorable for the development of peat swamps; (3) the $\mathrm{N}-\mathrm{S}$ polarity prevailed over the E-W polarity during the development of the coal-bearing capacity of the Petřkovice Member. Evidence for this statement is the higher coal-bearing capacity area occuring only in the south-western part of the basin. However, this is also affected by the great variability in seam number and in their total thickness. In the remaining parts of the basin the coal-bearing capacity shows very low values.

The coal-bearing capacity obviously depends on a number of factors that created a suitable environment for coal-bearing sedimentation in the basin and also affected the preservation and subsequent transformation of the organic matter. As emerges from our study, these factors include the subsidence of the basin floor and the overall lithological evolution of the succession, as well as the cyclic development of the deposits. These factors are mainly the results of the spatial development of the palaeogeography of the basin. The authors consider they have played the major role in the process of coal-bearing capacity formation. The models of sand content development (Hýlová et al., 2013) and of coal-bearing capacity show that the environments suitable for the coal-bearing sedimentation are characterized by a certain optimum sand content. Sand-rich or even sand-dominated sediments are not favourable for the formation of peat swamps, because a steady supply of clastic sediments suppressed vegetation growth. As a result, coal-bearing areas of the basin are generally the same areas where the best cyclic structure of sediments can be observed. On the other hand, not all fine-grained sediments or silts were favourable for the development of coal-bearing sedimentation, because some of them represent large seawater incursions to the peat swamps. These relationships between prevailing sediment type and coal-bearing capacity undoubtedly relate to the type of environment in which the coal-bearing sedimentation has the best conditions for its origin and development. Fossil swamps of the Petřkovice Member were mainly confined to the floodplain environment of streams, but also to near-shore lakes in relative proximity to the sea. Although our findings on the relationships between coal-bearing sedimentation, sedimentary environment and cyclicity in the basin may not have general applicability, the model of depositional environments presented and their relationship to the coal-bearing sedimentation is very close to that published by Havlena (1982), and also to the views presented by Kędzior et al. (2007) and others.

\section{CONCLUSIONS}

Spatial development of the coal-bearing capacity illustrates the lateral variability of depositional conditions of coal basins. In combination with tracking the additional parameters, such as overall thickness and sand-content, this may facilitate better characterization and understanding of the variability of the sedimentary environments in the basin.

From the viewpoint of the origin of the Petřkovice Member, it can be stated that the coal-bearing sedimentation of this unit was considerably influenced by the transition from shallow open marine sedimentation of the Kyjovice Member (equivalents in Polish part of the basin are the Malinowice and Zalas beds) to paralic sedimentation of the Ostrava Formation (Paralic Series in the Polish part of the basin). Coal-bearing sedimentation developed to a greater extent, at first, in the south of the basin (i.e., to the south in the Czech part). At this point, the north and northeast parts of the basin remained under significant influence of the marine incursions, where conditions for the development of coal-bearing sedimentation were generally unfavourable and time-limited. The places of the highest organic matter accumulation in the Petrrkovice Member were located mainly in the areas of maximum subsidence of the basin floor (foredeep segment), and partly in the transitional zone. In the zone of minimum subsidence, organic matter accumulation occurred only locally or was completely absent. The coal-bearing capacity of the Petřkovice Member was, therefore, controlled by the basin floor subsidence and partly also was influenced by fluctuations in depositional conditions at the northern part of the basin, which probably prevented more frequent marine incursions than in the southern parts of the basin, thus allowing it to partially increase the coal-bearing capacity in some areas.

The conditions described of the Petřkovice Member that influenced the coal-bearing capacity are the reason why this unit, as far as the coal-bearing capacity is concerned, is largely different from that of younger strata units in the paralic molasse of the USB. Perhaps due to such conditions, the development of the coal-bearing capacity of the Petřkovice Member may serve as an interesting example of the development of coal-bearing sedimentation in basins where transitional processes in sedimentary evolution from marine to paralic environments took place.

Acknowledgements. This study was made possible thanks to a grant from the Ministry of Education, Youth and Sports of the Czech Republic (project SGS SP2014/40). The authors are grateful to $A$. Kędzior and an anonymous reviewer for their constructive remarks and suggestions, which substantially improved the quality of the manuscript.

\section{REFERENCES}

Adamusová, M., Dopita, M., Foldyna, J., Kalendová, J., Kumpera, O., Strakoš, Z., 1992. The isopachous and coalification maps of coal bearing molasses in the Czechoslovak part of the Upper Silesian Black Coal Basin. Sborník vědeckých prací Vysoké školy báňské $v$ Ostravě, řada hornicko-geologická, 38: 27-36.

Aust, J., Čechová, Š., Hozza, L., Kaštovský, V., Krůl, M., Raszyková, L., Šmitková, Š., 1997. Uncovered geological map of the Czech part of the Upper Silesian Basin 1:100 000. Ministry of the Environment of the Czech Republic, Praha.

Buła, Z., 2000. The Lower Palaeozoic of Upper Silesia and West Małopolska (in Polish with English summary). Prace Państwowego Instytutu Geologicznego, 171: 1-63.

Buła, Z., Habryn, R., Jachowicz-Zdanowska, M., Żaba, J., 2015. The Precambrian and lower Paleozoic of the Brunovistulicum (eastern part of the Upper Silesian Block, southern Poland) the state of the art. Geological Quarterly, 59 (1): 123-134. 
Davydov, V.I., Korn, D., Schmitz, M.D., 2012. The Carboniferous Period. In: The Geologic Time Scale 2012 (eds. F. M. Gradstein, J. G. Ogg, M. Schmitz and G. Ogg), 2: 603-651. Elsevier, Oxford.

Dembowski, Z., 1972. General information on the Upper Sielsian Coal Basin (in Polish with English summary). Prace Instytutu Geologicznego, 61: 9-22.

Doktorowicz-Hrebnicki, S., 1935. Mapa szczegółowa Polskiego Zagłębia Węglowego 1:25,000. Arkusz Grodziec: Objaśnienie (in Polish with French summary). Państwowy Instytut Geologiczny, Warszawa.

Dopita, M., Aust, J., Brieda, J., Černý, I., Dvořák, P., Fialová, V. Foldyna, J., Grmela, A., Grygar, R., Hoch, I., Honěk, J., Kaštovský, V., Konečný, P., Kožušníková, A., Krejčí, B., Kumpera, O., Martinec, P., Merenda, M., Müller, K., Novotná, E., Ptáček, J., Purkyňová, E., Řehoř, F., Strakoš, Z., Tomis, L., Tomšík, J., Valterová, P., Vašíček, Z., Vencl, J., Žídková, S., 1997. Geology of the Czech Part of the Upper Silesian Basin (in Czech with English summary). Ministerstvo životního prostředí České republiky, Praha.

Dudek, A., 1980. The crystalline basement block of the Outer Carpathians in Moravia: Bruno-Vistulicum. Rozpravy Československé akademie věd, Řada matematických a prírodních věd, 90: 1-85.

Filák, P., 2006. Vliv fluviálních systémů na vývoj slojí petřkovických vrstev v dobývacím prostoru Stařič (in Czech). Ph.D. thesis, Faculty of Mining and Geology, Vysoká škola báňská - Technical University of Ostrava, Ostrava.

Folprecht, J., 1928. Das Kohlenvermögen des Revieres (in German and Czech). In: Der Kohlenbergbau des Ostrau-Karviner Steinkohlenreviers, I. Band: 341-344. Direktoren-Konferenz des Ostrau-Karviner Steikohlenreviers in Mährisch Ostrau, Mährisch Ostrau.

Francu, E., Francu, J., Kalvoda, J., Poelchau, H.S., Otava, J., 2002. Burial and uplift history of the Palaeozoic Flysch in the Variscan foreland basin (SE Bohemian Massif, Czech Republic). EGU Stephan Mueller Special Publication Series, 1: 167-179.

Gabzdyl, W., 1994. Geologia złóż węgla: Złoża świata (in Polish). Wydawnictwo Polskiej Agencji Ekologicznej, Warszawa.

Gastaldo, R.A., Purkyňová, E, Šimůnek, Z., Schmitz, M.D., 2009. Ecological persistence in the Late Mississippian (Serpukhovian, Namurian A) megafloral record of the Upper Silesian Basin, Czech Republic. Palaios, 24: 336-350.

Havlena, V., 1964. Geologie uhelných ložisek 2 (in Czech). Nakladatelství Československé akademie věd, Praha.

Havlena, V., 1982. The Namurian deposits of the Upper Silesian Basin. Rozpravy Československé akademie věd, Řada matematických a prírodních věd, 92: 1-41.

Hýlová, L., 2011. Geologie petřkovických vrstev hornoslezské pánve (ostravské souvrství, namur) (in Czech). Ph.D. thesis, Faculty of Mining and Geology, Vysoká škola báňská - Technical University of Ostrava, Ostrava.

Hýlová, L., Jureczka, J., Jirásek, J., Sivek, M., Hotárková, J., 2013. The Petřkovice Member (Ostrava Formation, Mississippian) of the Upper Silesian Basin (Czech Republic and Poland). International Journal of Coal Geology, 106: 11-24.

Jansa, L., Tomšík, J., 1960. Použití metody faciálně cyklické analýzy v ostravsko-karvínském karbonu (in Czech). Pracovní metody geologické služby, 1: 1-68.

Jirásek, J., Hýlová, L., Sivek, M., Jureczka, J., Martínek, K., Sýkorová, I., Schmitz, M., 2013a. Major Mississippian volcaniclastic unit of the Upper Silesian Basin, the Main Ostrava Whetstone: composition, sedimentary processes, palaeogeography and geochronology. International Journal of Earth Sciences, 102: 989-1006.

Jirásek, J., Sedláčková, L., Sivek, M., Martínek, K., Jureczka, J., 2013b. Castle Conglomerate Unit of the Upper Silesian Basin (Czech Republic and Poland): a record of the onset of Late Mississippin C2 glaciation? Bulletin of Geosciences, 88: 893-914.
Jurczak-Drabek, A., 1996. Petrographical Atlas of Coal Deposits Upper Silesian Coal Basin. Państwowy Instytut Geologiczny, Warszawa.

Jureczka, J., 1988. New data on the lithostratigraphic characteristics of the Paralic Series and Upper Silesian Sandstone Series contact in the Carboniferous sequence of the western part of the USCB (in Polish with English abstract). In: XI Sympozjum Geologia formacji węglonośnych Polski (ed. I. Lipiarski): 41-46. Wydawnictwo AGH, Kraków.

Jureczka, J., Dopita, M., Gałka, M., Krigier, W., Kwarciński, J., Martinec, P., 2005. Geological Atlas of Coal Deposits of the Polish and Czech Parts of the Upper Silesian Coal Basin. Państwowy Instytut Geologiczny, Ministerstwo Środowiska, Warszawa.

Jureczka, J., Kotas, A., 1995. Coal deposits: Upper Silesian Coal Basin. Prace Państwowego Instytutu Geologicznego, 148: 164-172.

Kalvoda, J., Babek, O., Fatka, O., Leichmann, J., Melichar, R., Nehyba, S., Spacek, P., 2008. Brunovistulian terrane (Bohemian Massif, Central Europe) from late Proterozoic to late $\mathrm{Pa}$ leozoic: a review. International Journal of Earth Sciences, 97: 497-518.

Kandarachevová, J., Sedláčková, L., Hýlová, L., Jirásek, J. Sivek, M., 2009. Lateral development of coalification in the Czech part of the Upper Silesian Coal Basin and its connection with gas deposits. International Journal of Coal Geology, 78: 225-232.

Kaštovský, V., Dopita, M., 1997. Coal-bearing capacity and coal reserves (in Czech with English summary). In: Geology of the Czech Part of the Upper Silesian Basin (ed. M. Dopita): 149-152. Ministerstvo životního prostředí České republiky, Praha.

Kędzior, A., Gradziński, R., Doktor, M., Gmur, D., 2007. Sedimentary history of a Mississippian to Pennsylvanian coal-bearing succession: an example from the Upper Silesia Coal Basin, Poland. Geological Magazine, 144: 487-496.

Konstantynowicz, E., 1994. Geologia złóż kopalin (in Polish). Wydawnictwo Uniwersytetu Śląskiego, Katowice.

Kotas, A., Buła, Z., Jureczka, J., 1988. Lithostratigraphic classification problems of the Upper Silesian Sandstone Series in view of the stratigraphic code requirements (in Polish with English abstract). In: XI Sympozjum Geologia formacji węglonośnych Polski (ed. I. Lipiarski): 55-61. Wydawnictwo AGH, Kraków.

Kotas, A., Malczyk, W., 1972. The Paralic Series of the Lower Namurian stage of the Upper Silesian Coal Basin (in Polish with English summary). Prace Instytutu Geologicznego, 61: 329-426.

Kroner, U., Mansy, J.-L., Mazur, S., Aleksandrowski, P., Hann H.P., Huckriede, H., Lacquement, F., Lamarche, J., Ledru, P., Pharaoh, T.C., Zedler, H., Zeh, A., Zulauf, G., 2008. Variscan tectonics. In: The Geology of Central Europe, 1: Precambrian and Palaeozoic (ed.T. McCann): 599-664. The Geological Society, London.

Kumpera, O., Martinec, P., 1995. The development of the Carboniferous accretionary wedge in the Moravian-Silesian Paleozoic Basin. Journal of the Czech Geological Society, 40: 47-64.

Malon, A., Tymiński, M., 2014. Węgiel kamienny (in Polish). In: Bilans zasobów złóż kopalin w Polsce wg stanu na 31 XII 2013 r. (eds. M. Szuflicki, A. Malon and M. Tymiński): 40-50. Państwowy Instytut Geologiczny - Państwowy Instytut Badawczy, Warszawa.

Martinec, P, Jirásek, J., Kožušníková, A., Sivek, M., eds., 2005. Atlas of Coal - the Czech part of the Upper Silesian Basin (in Czech with English summary). Anagram, Ostrava.

Menning, M., Alekseev, A.S., Chuvashov, B.I., Davydov, V.I., Devuyst, F.-X., Forek, H.C., Grunt, T.A., Hance, L., Heckel, P.H., Izokh, N.G., Jin, Y.-G., Jones, P.J., Kotlyar, G.V., Kozur, H.W., Nemyrovska, T.I., Schneider, J.W., Wang, X.-D., Weddige, K., Weyer, D., Work, D.M., 2006. Global time scale and regional stratigraphic reference scales of Central and West Europe, East Europe, Tethys, South China, and North America as used in the Devonian-Carboniferous-Permian Correlation 
Chart 2003 (DCP 2003). Palaeogeography, Palaeoclimatology, Palaeoecology, 240: 318-372.

Narkiewicz, M., 2007. Development and inversion of Devonian and Carboniferous basins in the eastern part of the Variscan foreland (Poland). Geological Quarterly, 51 (3): 231-256.

Pešek, J., Opluštil, S., Kumpera, O., Holub, V., Skoček V., Dvořák, J., Prouza, V., Tásler, R., 1998. Paleogeographic Atlas: Late Paleozoic and Triassic Formations, Czech Republic. Czech Geological Survey, Prague.

Sivek, M., Čáslavský, M., Jirásek, J., 2008. Applicability of Hilt's law to the Czech part of the Upper Silesian Coal Basin (Czech Republic). International Journal of Coal Geology, 73: 185-195.

Sivek, M., Dopita, M., Krůl, M., Čáslavský, Jirásek, J., 2003. Atlas of chemical-technological properties of coals in the Czech part of the Upper Silesian Basin. Vysoká škola báňská - Technical University of Ostrava, Ostrava.

Starý, J., Sitenský, I., Mašek, D., Hodková, T., Vaněček, M., Novák, J., Horáková, A., Kavina, P., 2014. Mineral commodity summaries of the Czech Republic 2014: Statistical data to 2013. Czech Geological Survey, Prague.

Unrug, R., 1966. L'évolution sédimentaire et tectonique du bassin hercynien de Moravie - Haute-Silésie. Bulletin de la Société Géologique de France, 7: 537-547.

Zeman, J., 1960. Megacyclothems in the Ostrava-Karviná District (in Czech with English summary). Věstník Ústředního ústavu geologického, 35: 299-313. 